\title{
COMPARATIVE NEST-SITE HABITAT OF PAINTED REDSTARTS AND RED-FACED WARBLERS IN THE MADREAN SKY ISLANDS OF SOUTHEASTERN ARIZONA
}

\author{
Joseph L. Ganey ${ }^{1,2}$, William M. Block ${ }^{1}$, Jamie S. Sanderlin ${ }^{1}$, and Jose M. Iniguez ${ }^{1}$
}

\begin{abstract}
AвSTRACT.-Conservation of avian species requires understanding their nesting habitat requirements. We compared 3 aspects of habitat at nest sites (topographic characteristics of nest sites, nest placement within nest sites, and canopy stratification within nest sites) of 2 related species of ground-nesting warblers (Red-faced Warblers, Cardellina rubrifrons, $n=17$ nests; Painted Redstarts, Myioborus pictus, $n=22$ nests) in the Sky Island mountain ranges of southeastern Arizona. These species nested in several forest and woodland cover types that occurred along an elevational gradient. Red-faced Warblers nested primarily toward the upper end of that gradient, in pine (Pinus spp.)-oak (Quercus spp.) and mixed-conifer forests. Painted Redstarts nested primarily at lower elevations, in riparian forest, oak-pine woodlands, and pine-oak forest. The 2 species both nested in cover types that occurred at mid-elevations. Within these shared cover types, Red-faced Warblers nested at higher elevations and at nest sites with greater canopy cover $>10 \mathrm{~m}$ aboveground than Painted Redstarts. Nest placement within nest sites was similar between species; both placed their nests in concealed locations. Our results suggest that managers should consider the entire elevational gradient surveyed here to best conserve habitat for both species, and should maintain at least some areas with relatively dense understory cover across that gradient to provide cover for nest sites. Managers should emphasize lower overstories in lower-elevation oak-pine woodlands, taller overstories in higher-elevation pine-oak and especially mixed-conifer forests, and a mixture of overstory heights in mid-elevation pine-oak forests. We recommend additional detailed studies of nesting habitat and the effects of disturbance processes on nesting habitat. Such studies will add to our understanding of the ecology of these 2 bird species and habitat conservation in this ecologically important area.
\end{abstract}

RESUMEn.-La conservación de especies de aves requiere comprender sus requisitos hábitat de anidación. Comparamos 3 aspectos del hábitat de anidación (características de los sitios de nido, colocación de nidos entre lugares de anidación, estratificación de las copas en los lugares de anidación) de 2 especies reinitas (o currucas) que anidan en el suelo (reinita cara-roja, Cardellina rubifrons, $n=17$; candelita pintada, Myioborus pictus, $n=22$ ) en las Islas montañas de el sureste de Arizona. Estas especies anidan en varios bosques y tierras arboladas que se producen a lo largo de un gradiente altitudinal. Reinitas cara-roja principalmente anidan en las partes mas altas del gradiente en bosques de pino (Pinus spp.)-encino (Quercus spp.) y bosques de coniferas mixtas, y los nidos de candelita pintado ocurrieron in las elevaciones más bajas principalmente en arboladas de encino con pine, y bosques de pino-encino. Sin embargo, ambas especies anidan en bosques a elevaciones medianas. Dentro de estos bosques donde comparten, candelitas pintada hacen nidos an areas con mayor cubierta dorsal a $>10 \mathrm{~m}$ por encima del suelo comparado a reinitas cara-rojas. Colocacion de nidos dentro de sitios de anidación fueron similar entre las especies, las 2 especies colocan sus nidos en lugares ocultos. Nuestros resultados sugieren que los manejadores deben considerar todo el gradiente altitudinal considerado aqui para conservar el hábitat de las 2 especies y deben mantener por lo menos algunas areas con alta cobertura sotobosque distribuidas a traves de el gradiente para proporcionar la cobertura necesitada en las areas de nidos. Manegadores deben destacer estratos superiores mas bajas en arbolados de encino con pine en las elevacionas mas bajas, y estratos superiores mas altas en los bosques de pino-encino en las elevaciones mas altas especialmente in los bosques de coníferas mixtas, y una mezcla the estratos superiores de differente alturas in las elevacionas medias con bosques de pino-encino. Recomendamos estudios mas detallados de hábitat de anidación de estas especies, y los efectos de la perturbación en su hábitat para entender mas la ecologia de estas especies y conservar su habitat en estas areas que son tan importantes ecologicamente.

The Madrean Sky Island mountain ranges of southeastern Arizona and adjacent Mexico harbor a unique and world-famous avifauna created by the mixing of Madrean and Cordilleran flora and fauna (Warshall 1995). This avifauna features several species that reach the northern limit of their range exclusively or primarily within the Sky Islands (e.g., Marshall 1957, Balda 1967, Gelbach 1981, Ganey et al. 1996, Flesch 2014). These include 2 related species of ground-nesting warblers, the Redfaced Warbler (Cardellina rubrifrons) and the

${ }^{1}$ USDA Forest Service, Rocky Mountain Research Station, Flagstaff, AZ.

${ }^{2} \mathrm{E}$-mail: jganey@fs.fed.us 
Painted Redstart (Myioborus pictus; Martin and Barber 1995, Barber et al. 2000, Corman and Wise-Gervais 2005). A recent analysis places Cardellina and Myioborus wood warblers as sister clades on a phylogenetic tree of the family Parulidae (Lovette et al. 2010). Both species occur throughout the highlands of Mexico and the southwestern United States, breeding as far north as central Arizona (Marshall and Balda 1974, Martin and Barber 1995, Barber et al. 2000, Corman and Wise-Gervais 2005, Kirkpatrick and Conway 2010, Flesch 2014).

There are no current estimates of population trend for either of these species (Corman and Wise-Gervais 2005), but the Red-faced Warbler is a species of high conservation priority in Arizona (Latta et al. 1999). Populations of both species may be particularly vulnerable to habitat loss or degradation within the Sky Island ranges because the forests and woodlands where breeding occurs encompass a relatively small portion of the landscape. In recent decades, these ranges have been impacted by a series of large wildfires (Sanderlin et al. 2013) resulting from a century of fire suppression interacting with climate-changeinduced droughts (Coe et al. 2012). These fires undoubtedly impacted breeding birds and their habitats (Ganey et al. 1996, Corman and Wise-Gervais 2005, Coe et al. 2012, Sanderlin et al. 2013), but our understanding of those impacts is limited by a general lack of knowledge about species ecology for most taxa (Ganey et al. 1996), including the Redfaced Warbler and Painted Redstart. Although Kirkpatrick and Conway (2010) studied nesting habitat of Red-faced Warblers in the Santa Catalina Mountains, many aspects of the ecology of these species elsewhere in the Sky Islands remain poorly understood (Martin and Barber 1995, Barber et al. 2000, Flesch 2014).

Conservation of avian species requires understanding their nesting habitat requirements, and identifying and providing habitat features that favor nesting success (Martin 1992). This is particularly important for species of conservation concern in areas such as the Sky Islands that are essential for maintaining regional biodiversity (Kirkpatrick and Conway 2010). Better knowledge of nest-site characteristics of Red-faced Warblers and Painted Redstarts is needed to facilitate the conser- vation of populations of these species. In addition, understanding comparative nest-site use is important because coexisting groundnesting bird species can exert profound ecological effects on one another, including displacement from preferred nest sites (Martin 1993, Martin and Martin 2001, Kirkpatrick and Conway 2010).

In conjunction with a study of avian species richness and habitat associations in 5 Sky Island ranges in southeastern Arizona (Block et al. 1992, Sanderlin et al. 2013), we studied nest sites used by Red-faced Warblers and Painted Redstarts. Here, we compare 3 aspects of nest-site use between the 2 species: topographic characteristics of nest sites, nest placement within nest sites, and canopy stratification within nest sites. This analysis provides insight into comparative patterns of nesting habitat use by the related species in the Sky Islands and more information on their autecology. This information should aid managers charged with conserving habitat for these species in an era of changing climate and altered disturbance regimes, as well as researchers designing and conducting more detailed and badly needed studies on habitat relationships for these species.

\section{Study AREA}

Our study area included the Chiricahua, Huachuca, Pinaleño, Santa Catalina, and Santa Rita Mountains, all located in southeastern Arizona. Within these ranges, we searched for nests along 29 transects (4-8 transects per range) used for avian point counts in a separate study (see Block et al. 1992, Sanderlin et al. 2013). We randomly located transects within mid- to high-elevation forests and woodlands (elevation range $1470-3000 \mathrm{~m}$ ).

We recognized 5 forest and woodland cover types among our transects. These cover types were arrayed along an elevational gradient (Fig. 1), although cover types did not change strictly as a function of elevation because of differences in topographic features such as slope and aspect (Whittaker and Niering 1968, Iniguez et al. 2005). Various oaks (Quercus spp.) intermixed with other deciduous trees including Arizona sycamore (Platamus wrightii), maples (Acer spp.), and box-elder (Acer negundo) dominated riparian forests at lower elevations. Some riparian forests also had Arizona cypress 


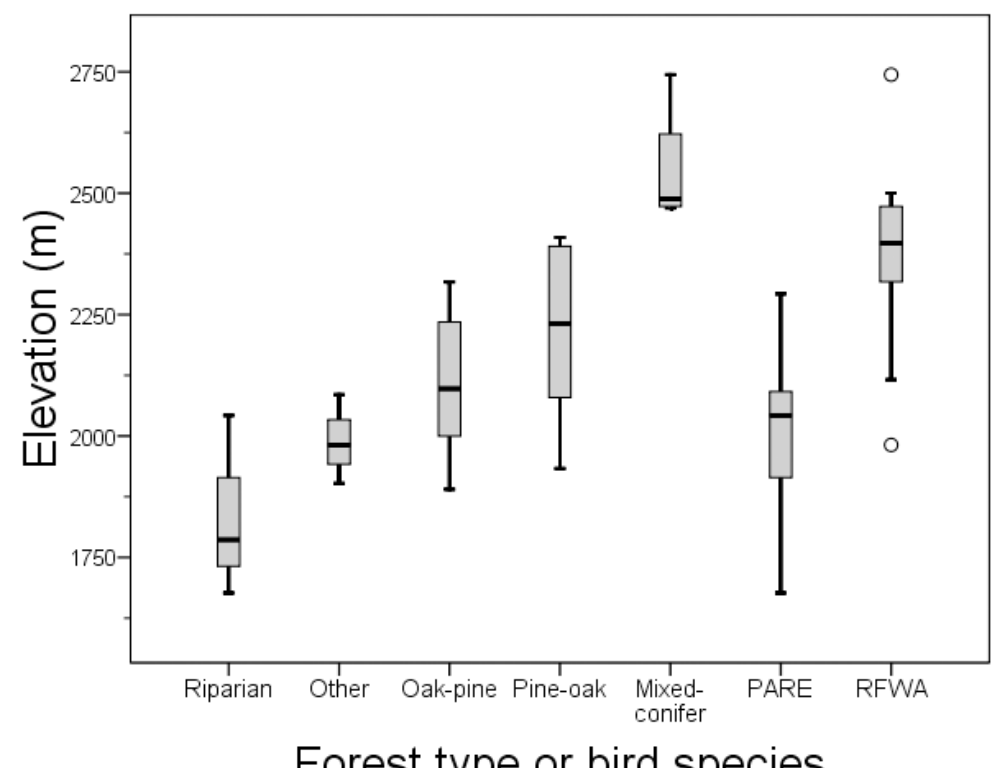

Fig. 1. Box plot showing elevation at nest sites of 2 species of ground-nesting warblers in the Sky Islands of southeastern Arizona by forest types, as well as elevation at all nests sampled for the 2 species (PARE $=$ Painted Redstart, $n=22$ nests; RFWA $=$ Red-faced Warbler, $n=17$ nests). The box conveys the range from the 25 th to the 75 th percentile, and the line within the box, the median. The external lines show the range in the data not including outliers (circles), defined as observations $>1.5$ times the box length outside the box.

(Cupressus arizonica) and other species of conifers. Oak-pine (Pinus spp.) woodlands generally occurred at slightly higher elevations. Various oaks, including Arizona white (Quercus arizonica), Emory (Quercus emoryi), and netleaf (Quercus reticulata) oaks dominated these woodlands. Typical pine species included border pinyon (Pinus discolor) and Chihuahua pine (Pinus leiophylla). Pine-oak forests broadly overlapped in elevation with oak-pine woodlands, although the former had a greater median elevation. Apache (Pinus engelmanni) and/or Chihuahua pines, and sometimes ponderosa (Pinus ponderosa) or Arizona (P. ponderosa var. arizonica) pines dominated the overstories here. The understory often had silverleaf oak (Quercus hypoleucoides) and sometimes Gambel oak (Quercus gambelii). Douglas-fir (Pseudotsuga menziesii) and/or white fir (Abies concolor), and sometimes southwestern white pine (Pinus strobiformis) dominated the mixed-conifer forests at the highest elevations. A final category (Other) included infrequently used cover types (e.g., pinyonjuniper woodlands, oak woodlands). In our study area, this category occurred at elevations intermediate between riparian forests and oak-pine woodlands (Fig. 1).

\section{Methods}

We located nests along transects used to conduct avian point counts in a separate study (Block et al. 1992, Sanderlin et al. 2013). Transects were approximately $3 \mathrm{~km}$ in length, and included terrain ranging from rolling hills to steep mountain slopes and canyons (Block et al. 1992, Sanderlin et al. 2013). We located nests by (1) observing foraging adults to see whether they took food to a nest, (2) accidentally flushing incubating birds from nests, or (3) locating calls of begging nestlings. We located all nests during the breeding season (April-July) from 1991 to 1995.

We sampled habitat at nest sites identified along the transects. To minimize disturbance to nesting birds, habitat sampling was designed to be rapid and minimally intrusive rather than detailed. For all nests located, we recorded the nest type, nest substrate (dead foliage or bare ground), forest cover type (described above), elevation (estimated from a 
USGS topographic map and converted to meters), mean slope, and slope aspect. We estimated mean slope $\left(^{\circ}\right)$ using 2 measures taken using a clinometer, one oriented uphill and one downhill. We estimated slope aspect $\left.{ }^{\circ}\right)$ along the major slope axis using a compass. We recorded the distance from each nest to the central stem of the nearest woody plant (nearest $0.1 \mathrm{~m}$ ). We visually estimated percent vegetation cover within $1 \mathrm{~m}$ above the nest, and within $1 \mathrm{~m}$ around the nest in each of the 4 cardinal directions. We averaged these 4 measures to estimate mean surrounding cover. We estimated overhead canopy cover in 4 vertical strata $(2-5 \mathrm{~m}, 5-10 \mathrm{~m}, 10-20 \mathrm{~m}$, and $>20$ $\mathrm{m})$ using point intercepts located at $1-\mathrm{m}$ intervals along four $5-\mathrm{m}$ line transects $(n=20$ points total). We positioned the transects in each cardinal direction, with starting points located at randomly determined distances between 1 and $20 \mathrm{~m}$ from the nest. At each point, we recorded presence/absence of overhead vegetation by strata and summed these canopy "hits" to estimate overall cover by strata.

We used exact chi-square tests to compare use of nest substrates and cover types between bird species. We modeled nest site use by the 2 species as a function of habitat covariates by using generalized linear models with a binary logistic response variable coded as 0 for Painted Redstarts and 1 for Red-faced Warblers. Because use of cover types varied significantly between species and habitat covariates likely varied among cover types, we included nest sites in models only from the 3 cover types that occurred at mid-elevations and were used for nesting by both species (oak-pine woodlands, pine-oak forest, and other; Fig. 1). We evaluated 3 sets of models representing (1) topographic features of the nest site, (2) nest placement within the nest site, and (3) canopy stratification within the nest site. Models describing topographic characteristics of nest sites included elevation, slope, and the cosine of aspect (an index of relative northness ranging from -1 at due south to 1 at due north) as covariates. Models describing nest placement within the nest site included as covariates mean surrounding cover, percent cover within $1 \mathrm{~m}$ above the nest, and distance to the nearest woody plant. Finally, models describing canopy stratification within the nest site included the number of canopy hits in the 4 vertical strata described above. Because the covariates we evaluated differed in scale, we standardized all covariates to unit variance and mean zero to facilitate interpretation of parameter estimates (Legendre and Legendre 1998). No covariates included in model sets were highly correlated $\left(r_{s} \leq 0.445\right.$ for all pairs of variables).

We evaluated models in a model selection framework using Akaike's information criterion corrected for small sample size ( $\mathrm{AIC}_{c}$; Burnham and Anderson 2002). We ran all possible models in the $\mathrm{R}$ computing environment using the glmulti package (Calcagno 2013, R Core Team 2013). We ranked models by $\Delta \mathrm{AIC}_{c}$ and considered any models with $\Delta \mathrm{AIC}_{c}<2$ to be competing models (Burnham and Anderson 2002). We computed model weights after Burnham and Anderson (2002) and estimated relative covariate weights by summing model weights across all models containing that covariate. In this context, covariate weights were informative (Doherty et al. 2012) because all covariates were included in the same number of models. We calculated model-averaged parameter estimates and 95\% confidence intervals (CI) using unconditional variance (Burnham and Anderson 2002) for all covariates included in competing models. We present parameter estimates for standardized covariates, but all descriptive statistics presented refer to unstandardized covariates. Given our relatively small sample of nests, we were more interested in the relative importance of habitat covariates in predicting habitat use and the direction of observed relationships than in the parameter estimates themselves.

\section{RESUlTS}

We located 22 nests of Painted Redstarts and 17 nests of Red-faced Warblers. All nests for both species were in cups fashioned from herbaceous vegetation. All were placed on bare ground or in dead foliage on the ground. Use of these substrate types did not differ significantly between species $\left(\chi^{2}{ }_{1}=2.079, P=\right.$ 0.178 ), with $53 \%$ of nests placed on bare ground and the remainder in dead foliage. Use of vegetation cover types differed significantly $\left(\chi^{2}{ }_{4}=18.391, P<0.001\right)$ between species. Red-faced Warblers nested primarily in pineoak and mixed-conifer forest (Fig. 2). Painted Redstarts also nested in pine-oak forest but 


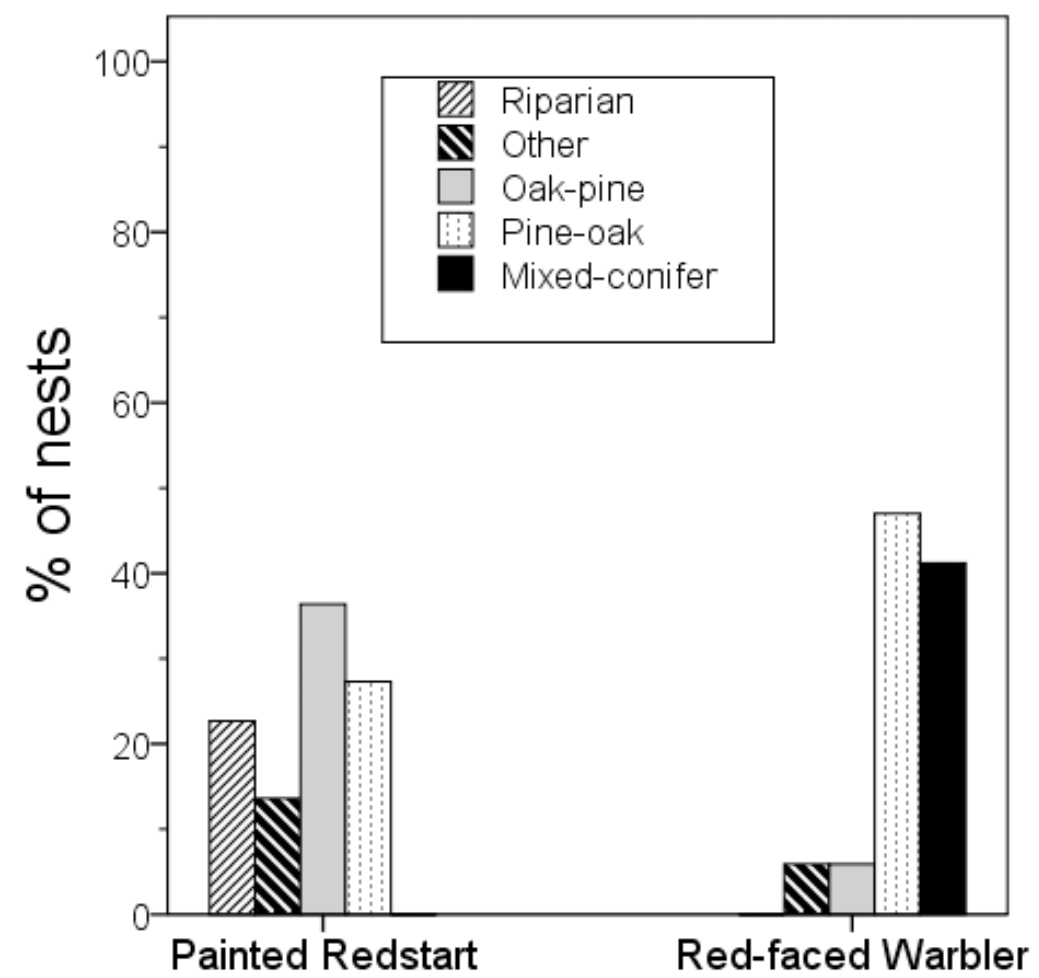

Fig. 2. Use of forest cover types for nesting by 2 species of warblers in the Madrean Sky Islands of southeastern Arizona. The results were based on 22 nests of Painted Redstarts and 17 nests of Red-faced Warblers. Category "other" included oak woodland and pinyon-juniper woodland. Cover types were arrayed from left to right in order of increasing elevation.

TABLE 1. Model selection results for models evaluating topographic characteristics of nest sites used by Painted Redstarts (17 nests) and Red-faced Warblers (10 nests) in forest types used for nesting by both species (oak-pine woodland, pine-oak forest, and "other") in the Sky Islands of southeastern Arizona.

\begin{tabular}{lcc}
\hline Model $^{\mathrm{a}}$ & $\Delta \mathrm{AIC}_{c} \mathrm{~b}^{\mathrm{b}}$ & Model weight $^{\mathrm{c}}$ \\
\hline Elevation & 0.0000 & 0.4769 \\
Elevation + Slope & 0.6511 & 0.3444 \\
Elevation + Cosine aspect & 2.7969 & 0.1178 \\
Elevation + Slope + Cosine aspect & 4.1210 & 0.0608 \\
Null & 17.8240 & $<0.0001$ \\
Slope & 19.3480 & $<0.0001$ \\
Cosine aspect & 20.3673 & $<0.0001$ \\
Slope + Cosine aspect & 22.1342 & $<0.0001$
\end{tabular}

aCovariates in candidate models included elevation $(\mathrm{m})$, slope $\left(^{\circ}\right.$ ), and cosine aspect (an index of relative northness ranging from -1 at due south to 1 at due north.

bChange in Akaike's information criterion corrected for small sample size, relative to the model with lowest $\mathrm{AIC}_{c}$.

${ }^{\mathrm{c}}$ Model weights calculated following Burnham and Anderson (2002).

more commonly nested in oak-pine woodland and riparian forests.

Ten nests of Red-faced Warblers and 17 nests of Painted Redstarts were found in forest types used by both species. Use of cover types did not differ significantly between warbler species in this restricted sample $\left(\chi^{2}{ }_{2}=5.270\right.$, $P=0.081)$. Collectively, $52 \%$ of included nest sites were in pine-oak forest, $33 \%$ were in oakpine woodlands, and $15 \%$ were in other cover types.

Two competing models described topographic characteristics of nest sites in shared cover types, and these models contributed $>82 \%$ of collective model weight (Table 1). The top model included only elevation and 
TABLE 2. Model selection results for models evaluating nest placement within nest sites by Painted Redstarts (17 nests) and Red-faced Warblers (10 nests) in forest types used for nesting by both species (oak-pine woodland, pine-oak forest, and "other") in the Sky Islands of southeastern Arizona.

\begin{tabular}{llr}
\hline Model $^{\mathrm{a}}$ & $\Delta \mathrm{AIC}_{c}^{\mathrm{b}}$ & Model weightc $^{\mathrm{b}}$ \\
\hline Distance & 0.0000 & 0.5722 \\
Distance + Surrounding cover & 2.4026 & 0.1721 \\
Distance + Cover above & 2.8082 & 0.1405 \\
Null & 5.0410 & 0.0460 \\
Distance + Surrounding cover + Cover above & 5.7996 & 0.0315 \\
Surrounding cover & 7.0627 & 0.0168 \\
Cover above & 7.0945 & 0.0165 \\
Surrounding cover + Cover above & 9.7400 & 0.0044
\end{tabular}

a Covariates in candidate models: Distance $=$ distance to nearest plant $(0.1 \mathrm{~m})$, Surrounding cover $=$ mean $\%$ cover within $1 \mathrm{~m}$ around the nest, Cover above $=$ $\%$ cover within $1 \mathrm{~m}$ above the nest.

${ }^{b}$ Change in Akaike's information criterion corrected for small sample size, relative to the model with lowest AIC $_{c}$.

${ }^{\mathrm{c}}$ Model weights calculated following Burnham and Anderson (2002).

TABLE 3. Model selection results for models evaluating canopy stratification within nest sites of Painted Redstarts (17 nests) and Red-faced Warblers (10 nests) in forest types used for nesting by both species (oak-pine woodland, pine-oak forest, and "other") in the Sky Islands of southeastern Arizona.

\begin{tabular}{lcc}
\hline Model $^{\mathrm{a}}$ & $\Delta \mathrm{AIC}_{c}{ }^{\mathrm{b}}$ & Model weight $^{\mathrm{c}}$ \\
\hline Canopy strata $3+4$ & 0.0000 & 0.4877 \\
Canopy stratum 4 & 1.7128 & 0.2071 \\
Canopy strata $2+3+4$ & 3.6983 & 0.0767 \\
Canopy strata $1+3+4$ & 3.7956 & 0.0731 \\
Canopy strata $1+4$ & 4.5790 & 0.0494 \\
Canopy strata $2+4$ & 4.6705 & 0.0472 \\
Canopy stratum 3 & 5.9734 & 0.0246 \\
Canopy strata $1+2+3+4$ & 7.6790 & 0.0105 \\
Canopy strata $1+2+4$ & 8.0555 & 0.0087 \\
Canopy strata $1+3$ & 8.4651 & 0.0065 \\
Canopy strata $2+3$ & 8.7216 & 0.0062 \\
Canopy strata $1+2+3$ & 11.5662 & 0.0015 \\
Null & 14.6209 & 0.0003 \\
Canopy stratum 1 & 15.1288 & 0.0003 \\
Canopy stratum 2 & 16.0196 & 0.0002 \\
Canopy strata 1 + 2 & 17.0559 & 0.0001 \\
\hline
\end{tabular}

${ }^{\mathrm{a} C o v a r i a t e s ~ i n ~ c a n d i d a t e ~ m o d e s ~ r e p r e s e n t e d ~ r e l a t i v e ~ c a n o p y ~ c o v e r ~ i n ~} 4$ vertical strata $(1=2-5 \mathrm{~m}, 2=5-10 \mathrm{~m}, 3=10-20 \mathrm{~m}$, and $4=>20 \mathrm{~m})$.

bChange in Akaike's information criterion corrected for small sample size, relative to the model with lowest $\mathrm{AIC}_{c}$.

cModel weights calculated following Burnham and Anderson (2002).

the competing model elevation and slope. Model-averaged parameter estimates indicated that Red-faced Warblers nested at higher elevation $(\widehat{\beta}$ elevation $=0.4908$, CI $0.3633-0.6182)$ and on steeper slopes ( $\hat{\beta}$ slope $=0.0440$, CI -0.0216 to 0.1096 ) than Painted Redstarts. However, the confidence interval for slope overlapped zero, suggesting that this covariate contributed less to the model than elevation. Relative covariate weights within the candidate model set also supported greater importance for elevation (0.9999) than for slope (0.4052), and little importance for cosine aspect $(0.1786)$. Empirical data supported these patterns, with elevation within these cover types averaging $2289 \mathrm{~m}$ (CI 2158-2420 m) at Red-faced Warbler nests and $2052 \mathrm{~m}$ (CI 1974-2130 m) at
Painted Redstart nests. In contrast, slope differed far less between species (Red-faced Warbler $\bar{x}=34.1^{\circ}\left[\right.$ CI $\left.15.4^{\circ}-52.9^{\circ}\right]$, Painted Redstart $\bar{x}=29.2^{\circ}\left[\right.$ CI $\left.15.6^{\circ}-42.7^{\circ}\right]$ ).

We obtained only one competitive model for nest placement within the nest site, which contributed $57 \%$ of model weight (Table 2). This model included only distance to the nearest woody plant. The model-averaged parameter estimate indicated that Red-faced Warblers placed nests closer to the nearest plant than Painted Redstarts $(\hat{\beta}$ distance $=-0.1189$, CI -0.2280 to -0.0098$)$. Covariate weights within the candidate model set also indicated that distance to nearest plant (0.9163) contributed more to these models than cover around the nest $(0.2248)$ or cover above the 


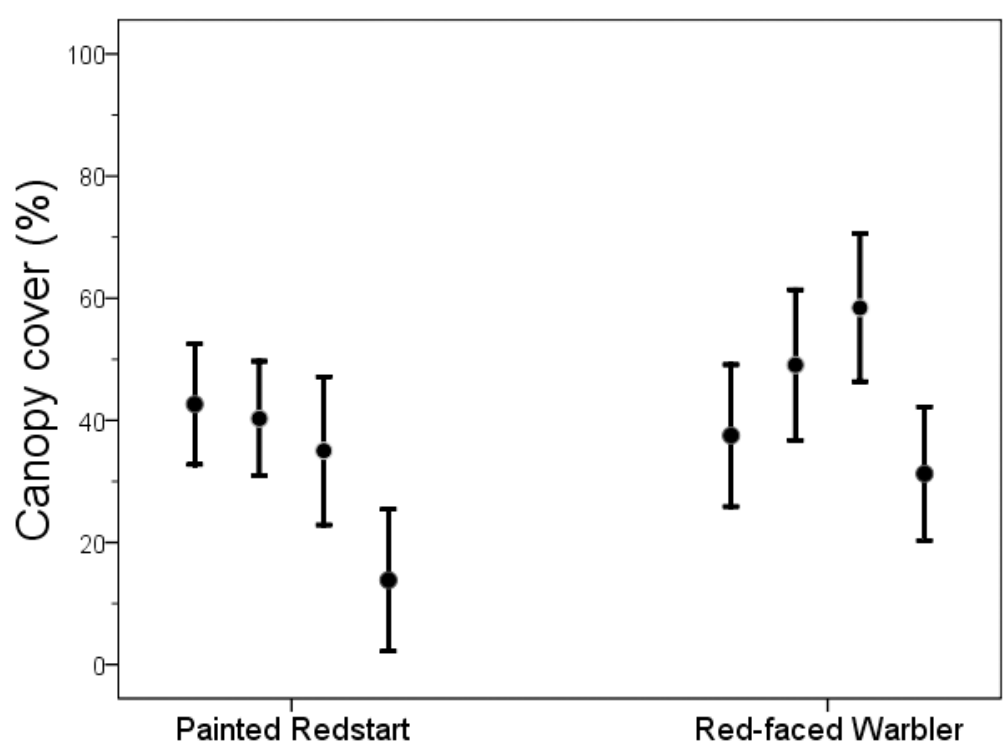

Fig. 3. Percent overhead canopy cover (mean, whisker bars represent the $95 \%$ confidence interval) for 4 vertical strata at nest sites of Painted Redstarts and Red-faced Warblers in the Sky Islands of southeastern Arizona. From left to right, strata represented cover from 2-5 m, 5-10 m, 10-20 m, and >20 m aboveground. The results were based on 17 nests of Painted Redstarts and 10 nests of Red-faced Warblers found in forest types where both species nested (oak-pine woodland, pine-oak forest, and "other").

nest (0.1930), and confidence intervals around parameter estimates overlapped zero for all variables except distance. However, empirical data suggested that distance to the nearest plant differed only slightly between species (mean was $1.0 \mathrm{~m}$ [CI $0.2-1.9 \mathrm{~m}$ ] for Red-faced Warbler nests and $1.6 \mathrm{~m}$ [CI $1.0-2.2 \mathrm{~m}$ ] for Painted Redstart nests). Mean cover surrounding the nest averaged $57.8 \%$ (CI 46.0\%-69.7\%) for both species combined, and mean cover above the nest averaged $75.3 \%$ (CI $62.0 \%$ $88.5 \%)$, indicating that both species placed nests in well-concealed locations.

Two competing models described vertical canopy stratification within nest sites (Table 3). The top model included canopy cover 10-20 m aboveground and $>20 \mathrm{~m}$ aboveground, and carried $>48 \%$ of collective model weight. The competing model included only canopy cover $>20 \mathrm{~m}$ aboveground, and carried $21 \%$ of model weight. Model-averaged parameter estimates indicated that canopy cover in both strata was greater at Red-faced Warbler nests than at Painted Redstart nests $(\hat{\beta}$ cover $10-20 \mathrm{~m}=$ 0.1350 , CI $0.0165-0.2535, \hat{\beta}$ cover $>20 \mathrm{~m}=$ 0.2632 , CI 0.1313-0.3410). Confidence intervals around parameter estimates for these 2 canopy strata did not overlap zero, and covari- ate weights were greater for these strata (0.6868 for canopy 10-20 m aboveground and 0.9604 for canopy $>20 \mathrm{~m}$ aboveground) than for canopy cover $2-5 \mathrm{~m}$ aboveground (0.1500) and $5-10 \mathrm{~m}$ aboveground (0.1511). Canopy cover at Painted Redstart nests peaked at 2-5 $\mathrm{m}$ aboveground and declined through all higher strata (Fig. 3). In contrast, canopy cover at Red-faced Warbler nests increased steadily from strata 1 through 3 , reaching its peak at 10-20 $\mathrm{m}$ aboveground.

\section{Discussion}

The 2 warbler species we studied nested in several cover types arrayed along an elevational gradient. Red-faced Warblers concentrated nesting in higher-elevation forest types dominated by coniferous trees but containing oaks. In contrast, Painted Redstarts nested primarily at lower elevations in forest and woodland types featuring mixtures of oaks and conifers, with at least some of these types more likely to be dominated by oaks than conifers.

Nesting habitat for these species overlapped in several forest cover types within the central portion of the elevational gradient occupied. Within those shared cover types, we 
identified both similarities and differences between species in nesting habitat. Red-faced Warblers nested at higher elevations and in forests with greater canopy cover $>10 \mathrm{~m}$ aboveground within these shared cover types than did Painted Redstarts. However, nest placement within nest sites differed little between species, with both species placing nests in well-concealed locations adjacent to a woody plant. Red-faced Warblers placed their nests slightly closer to the nearest woody plant than did Painted Redstarts.

These results largely are consistent with existing studies. For example, Martin and Barber (1995) described breeding habitat for Red-faced Warblers as montane fir and pineoak forests between 2000 and $2800 \mathrm{~m}$, and Kirkpatrick and Conway (2010) located most Red-faced Warbler nests $\leq 30 \mathrm{~m}$ from drainage bottoms in forests containing mixtures of coniferous and deciduous trees. In a survey covering 26 Sky Island mountain ranges, Flesch (2014) reported that Red-faced Warblers were most common in conifer forests containing deciduous trees and shrubs, especially mixed-conifer forests, and density of Red-faced Warblers increased with elevation. All Red-faced Warbler nests observed along the Mogollon Rim in northern Arizona $(n=108)$ and in the Santa Catalina Mountains $(n=151)$ were on the ground, and most were located adjacent to woody plants, primarily white fir, Douglas-fir, or maples (Martin and Barber 1995, Kirkpatrick and Conway 2010). Redfaced Warbler nests in the Santa Catalina Mountains were positively associated with (1) cover of brush, Gambel oak saplings and small trees, and small woody debris; (2) fern and forb cover; (3) bigtooth maple (Acer grandidentatum) saplings and small trees; (4) large southwestern white pine trees; and (5) white fir and Douglas-fir saplings and small trees (Kirkpatrick and Conway 2010). Mean side concealment at these Red-faced Warbler nests was $46 \%$, slightly but not much lower than typical values observed in our study, and Redfaced warblers avoided nesting in areas impacted by low-severity wildfire (Kirkpatrick and Conway 2010). However, avoidance of areas burned by low-severity fire may be a short-term response. Such areas may provide suitable nesting habitat 3-4 years after fires as oak species resprout and conifers regenerate.
For Painted Redstarts, Barber et al. (2000; see also Marshall 1957, Balda 1967, Marshall and Balda 1974) described breeding habitat as primarily associations of oak and pine, and adjacent riparian woodlands. Flesch (2014) noted that Painted Redstarts occurred in several cover types, increased in abundance with increasing cover of oaks, and were most abundant in riparian habitat at moderate elevations. Painted Redstarts typically located their nests on the ground, on steep slopes, or in rocky walls; nests consistently were described as well concealed (Marshall 1957, Balda 1967, Marshall and Balda 1974, Barber et al. 2000).

The relatively high cover observed at most nests for both species in this study likely aids the birds in avoiding predators (Marshall and Balda 1974, Martin 1993, Martin and Barber 1995, Barber et al. 2000, Kirkpatrick and Conway 2010); and the diversity of small trees, saplings, and shrubs found at nest sites may also provide improved foraging opportunities (Franzreb and Franzreb 1983, Kirkpatrick and Conway 2010). Wildfire, including even lowseverity fire, can temporarily reduce the abundance of small trees, saplings, and shrubs typically associated with the nest sites of Redfaced Warblers (Kirkpatrick and Conway 2010) and possibly Painted Redstarts. This in turn may impact nesting success of these species. For example, Kirkpatrick and Conway (2010) observed greater depredation rates on nests of Red-faced Warblers and Yellow-eyed Juncos (Junco phaeonotus), another ground-nesting species, in the 2 years following a low-severity wildfire than in the 2 years preceding that fire. However, they also noted that low-severity fire could be important in improving habitat quality in the long term by stimulating growth of the understory vegetation that provides nesting cover and foraging opportunities.

No information is available on the effect of forest treatments on nesting habitat for Painted Redstarts, but a recent meta-analysis demonstrated that Red-faced Warblers responded strongly and negatively to both smalldiameter thinning treatments and selective harvest treatments (Kalies et al. 2010; see also Franzreb 1977, Szaro and Balda 1979a, 1979b). These treatments likely removed the cover required for nesting and foraging. Painted Redstarts may respond similarly, given the similarity between species in nest-site placement and concealment. This suggests that 
restoration treatments aimed at reducing fuel levels and continuity may negatively impact these species in the short term. As with wildfire, however, such treatments may be beneficial over longer time horizons if they stimulate understory growth and/or if they reduce the risk of moderate- or high-severity wildfire.

Our results, coupled with the limited existing data on nesting habitat for Painted Redstarts and Red-faced Warblers, suggest that management should encompass the entire elevational gradient and range of cover types evaluated here. Within these cover types, managers should retain at least some areas with relatively dense understory cover to provide the concealment needed for successful nesting. This could be accomplished by deferring some areas from treatments such as thinning, selective harvest, or prescribed fire, by staggering these activities across time so that some areas are always in different successional stages, and by arranging these areas spatially so that successional stages are well distributed across the elevational gradient occupied by these species. The observed differences between these warbler species in canopy cover by height stratum suggest that it may be desirable to manage for a mixture of areas featuring both relatively low and taller overstories. Painted Redstarts appeared to prefer lower overstories and typically occurred at lower elevations than Red-faced Warblers and in oak-pine woodlands and pine-oak forests. Managers could accommodate canopy requirements of both warbler species by managing for primarily lower overstories in lower-elevation oak-pine woodlands, taller overstories in higher-elevation sites and especially in mixed-conifer forests, and a mixture of overstory heights in mid-elevation pine-oak forests.

This study adds to our understanding of nesting habitat requirements for Painted Redstarts and Red-faced Warblers, but many questions remain. We still lack quantitative data on species composition and forest structure at nest sites, on how habitat composition and structure influences predation rates and nesting success, and on how forest treatments or disturbance processes such as wildfire impact nesting habitat for these species (but see Franzreb 1977, Szaro and Balda 1979a, 1979b, Kalies et al. 2010, Kirkpatrick and Conway 2010). Given the importance of nesting habitat to avian conservation (Martin 1992), as well as the marked changes occurring in vegetation composition/structure and avian communities in the Sky Islands in response to climate change, wildfire, and human activities (Ganey et al. 1996, Kirkpatrick and Conway 2010, Coe et al. 2012, Sanderlin et al. 2013, Flesch 2014), we recommend detailed and more spatially extensive studies of nesting habitat for these species.

\section{ACKNOWLEDGMENTS}

We thank the dedicated field crew members who labored hard to collect this data set, including L. Hall, C. Howell, L. Seguela, B. Maynard, M. Morrison, A. Rifa, P. Scott, R. Hoyer, R. Lange, J. Whittier, and R. Wilson. We thank the Coronado National Forest, Fort Huachuca, The Nature Conservancy, Santa Rita Experimental Station, and Audubon Research Ranch for logistical support. This paper was improved by comments from J. Hudon and 2 anonymous reviewers. We dedicate this work to R.P. Balda for his pioneering work on forest birds in Arizona.

\section{Literature Cited}

BALDA, R.P. 1967. Ecological relationships of the breeding birds of the Chiricahua Mountains, Arizona. Doctoral dissertation, University of Illinois, Urbana, IL.

Barber, D.R., P.M. Barber, and P.G. Jablonski. 2000. Painted Redstart (Myioborus pictus). No. 528 in A. Poole and F. Gill, editors, The Birds of North America. The Birds of North America, Inc., Philadelphia, PA.

Block, W.M., J.L. Ganey, K.E. SEverson, and M.L. MorriSON. 1992. Use of oaks by Neotropical migratory birds in the Southwest. Pages 65-70 in P.F. Ffolliott, G.J. Gottfried, D.A. Bennett, C. Hernandez, A. Ortega-Rubio, and R.H. Hamre, technical coordinators, Ecology and management of oak and associated woodlands: perspectives in the southwestern United States and northern Mexico. U.S. Forest Service General Technical Report RM-218, Rocky Mountain Forest and Range Experiment Station, Fort Collins, CO.

Burnham, K.P., AND D.R. ANDERSON. 2002. Model selection and multimodel inference: a practical informationtheoretic approach. 2nd edition. Springer-Verlag, New York, NY.

Calcagno, V. 2013. glmulti: Model selection and multimodel inference made easy. $\mathrm{R}$ package version 1.0.7. http://CRAN.R-project.org/package= glmulti

Coe, S.J., D.M. Finch, and M.M. Friggens. 2012. An assessment of climate change and the vulnerability of wildlife in the Sky Islands of the Southwest. General Technical Report RMRS-GTR-273, USDA Forest Service, Rocky Mountain Research Station, Fort Collins, CO. 
Corman, T.E., and C. Wise-Gervais. 2005. Arizona breeding bird atlas. University of New Mexico Press, Albuquerque, NM.

Doherty, P.F., G.C. White, and K.P. Burnham. 2012. Comparison of model building and selection strategies. Journal of Ornithology 152 (Supplement 2): 317-323.

FLeSCH, A.D. 2014. Distribution, abundance, habitat, and biogeography of breeding birds in the Sky Islands and adjacent Sierra Madre Occidental of northwest Mexico. Final report to U.S. National Park Service and U.S. Fish and Wildlife Service, CESU Agreement P08AC00077/J1212080048 and FWS Cooperative Agreement F12AP00566. School of Natural Resources and the Environment, University of Arizona, Tucson, AZ, and Division of Biological Sciences, University of Montana, Missoula, MT. 125 pp.

Franzreb, K.E. 1977. Bird population changes after timber harvesting of a mixed-conifer forest in Arizona. Research Paper RM-184, USDA Forest Service, Rocky Mountain Forest and Range Experiment Station, Fort Collins, CO.

Franzreb, K.E., And B.J. Franzreb. 1983. Foraging ecology of the Red-faced Warbler during the breeding season. Western Birds 14:31-38.

Ganey, J.L., W.M. Block, and P.F. Boucher. 1996. Effects of fire on birds in Madrean forests and woodlands. Pages 146-154 in P.F. Ffolliott, L.F. DeBano, M.B. Baker Jr., G.J. Gottfried, G. SolisGarza, C.B. Edminster, D.G. Neary, L.S. Allen, and R.H. Hamre, technical coordinators, Effects of fire on Madrean province ecosystems. General Technical Report RM-GTR-289, USDA Forest Service, Rocky Mountain Forest and Range Experiment Station, Fort Collins, CO.

GelbaCH, F.R. 1981. Mountain islands and desert seas: a natural history of the U.S.-Mexican borderlands. Texas A\&M University Press, College Station, TX.

Iniguez, J.M., J.L. Ganey, P.J. Dougherty, and J.D. Bailey. 2005. Using cluster analysis and a classification and regression tree model to identify cover types in the Sky Islands of southeastern Arizona. Pages 195-200 in G.J. Gottfried, B.S. Gebow, L.G. Eskew, and C.B. Edminster, compilers, Connecting mountain islands and desert seas: biodiversity and management of the Madrean Archipelago II. Proceedings RMRS-P-36, USDA Forest Service, Rocky Mountain Research Station, Fort Collins, CO.

Kalies, E.L., C.L. Chambers, and W.W. Covington. 2010. Wildlife responses to thinning and burning treatments in southwestern conifer forests: a metaanalysis. Forest Ecology and Management 259: 333-342.

KirkPatrick, C., AND C.J. ConWay. 2010. Importance of montane riparian forest and influence of wildfire on nest-site selection of ground-nesting birds. Journal of Wildlife Management 74:729-738.

Latta, M.J., C.J. Beardmore, and T.E. Corman. 1999. Arizona Partners in Flight Bird Conservation Plan. Version 1.0. Nongame and Endangered Wildlife Program Technical Report 142, Arizona Game and Fish Department, Phoenix, AZ.

LEgENDRE, P., AND L. LEgENDRE. 1998. Numerical ecology. 2nd edition. Elsevier, Amsterdam. 853 pp.
Lovette, I., J.L. Pérez-Emán, J.P. Sullivan, R.C. Banks, I. Fiorentino, S. Córdoba-Córdoba, M.A. EcheverryGalvis, F.K. Barker, K.J. Burns, J. Klicka, et al. 2010. A comprehensive multilocus phylogeny for the wood-warblers and a revised classification of the Parulidae (Aves). Molecular Phylogenetics and Evolution 57:753-770.

Marshall, J.T., Jr. 1957. Birds of the pine-oak woodland in southern Arizona and adjacent Mexico. Pacific Coast Avifauna 32:1-25.

Marshall, J., AND R.P. BALDA. 1974. The breeding ecology of the Painted Redstart. Condor 76:89-101.

MaRTin, T.E. 1992. Breeding productivity considerations: what are the appropriate habitat features for management? Pages 453-473 in J.M. Hagan and D.W. Johnston, editors, Ecology and conservation of Neotropical migrant land birds. Smithsonian Institution Press, Washington, DC.

Martin, T.E. 1993. Nest predation and nest sites. BioScience 43:523-532.

Martin, T.E., AND P.M. Barber. 1995. Red-faced Warbler (Cardellina rubrifrons). No. 152 in A. Poole and F. Gill, editors, The Birds of North America. The Birds of North America, Inc., Philadelphia, PA.

Martin, P.R., And T.E. Martin. 2001. Ecological and fitness consequences of species coexistence: a removal experiment with wood warblers. Ecology 82:189-206.

R Core Team. 2013. R: a language and environment for statistical computing. R Foundation for Statistical Computing, Vienna, Austria. http://www.R-project.org/

Sanderlin, J.S., W.M. Block, J.L. GaneY, and J.M. InigueZ. 2013. Preliminary assessment of species richness and avian community dynamics in the Madrean Sky Islands, Arizona. Pages 180-190 in G.J. Gottfried, P.F. Ffolliott, B.S. Gebow, L.G. Eskew, and L.C. Collins, compilers, Merging science and management in a rapidly changing world: biodiversity and management of the Madrean Archipelago III. Proceedings RMRS-P-67, USDA Forest Service, Rocky Mountain Research Station, Fort Collins, CO.

Szaro, R.C., AND R.P. BALDA. 1979a. Bird community dynamics in a ponderosa pine forest. Studies in Avian Biology 3:1-66.

SZARO, R.C., AND R.P. BALDA. 1979b. Effects of harvesting ponderosa pine on nongame bird populations. Research Paper RM-212, USDA Forest Service, Rocky Mountain Forest and Range Experiment Station, Fort Collins, CO.

Warshall, P. 1995. The Madrean Sky Island Archipelago: a planetary overview. Pages 6-18 in L.H. DeBano, P.H. Ffolliott, A. Ortega-Rubio, G.J. Gottfried, R.H. Hamre, and C.B. Edminster, technical coordinators, Biodiversity and management of the Madrean archipelago: the Sky Islands of southwestern United States and northwestern Mexico. General Technical Report RM-GTR-264, USDA Forest Service, Rocky Mountain Forest and Range Experiment Station, Fort Collins, CO.

WhitTaKer, R.H., AND W.A. NiERing. 1968. Vegetation of the Santa Catalina Mountains, Arizona. Arizona Journal of Ecology 56:523-544.

Received 11 August 2014 Accepted 23 May 2015 